\title{
Duplicate prescriptions-proposal of a clinically oriented categorisation
}

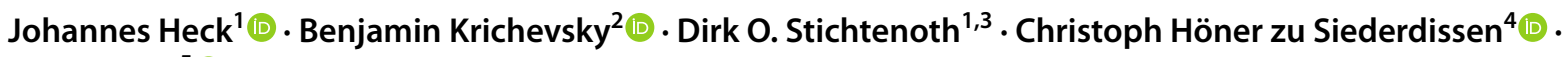 \\ Olaf Krause ${ }^{5}$
}

Received: 8 February 2021 / Accepted: 11 April 2021 / Published online: 23 April 2021

(c) The Author(s) 2021

Sir,

In clinical routine, we frequently encounter duplicate prescriptions. Duplicate prescriptions pose a risk factor for the development of adverse drug reactions and may increase healthcare expenditures. Literature on the prevalence of duplicate prescriptions is abundantly available [1-6]. However, to the best of our knowledge, a widely accepted definition of "duplicate prescription" has not been established to date. Van Leeuwen and colleagues, for instance, merely "define a duplicate prescription as the concurrent use of two drugs of the same class to treat the same condition" [2]. This definition neglects two important aspects. First, two drugs of different pharmacological classes, such as the combination of a proton pump inhibitor and a histamine $\mathrm{H}_{2}$ receptor antagonist, may also be considered a duplicate prescription. Second, two drugs of the same pharmacological class used in different therapeutic indications, such as the combination of diphenhydramine for nausea and vomiting

Johannes Heck and Benjamin Krichevsky have contributed equally to the preparation of this manuscript.

Christoph Höner zu Siederdissen and Olaf Krause have contributed equally to the preparation of this manuscript.

Johannes Heck

heck.johannes@mh-hannover.de

1 Institute for Clinical Pharmacology, Hannover Medical School, Hannover, Germany

2 Medical Service of the German Armed Forces, Kiel, Germany

3 Drug Commissioner of Hannover Medical School, Hannover, Germany

4 Emergency Department, Hannover Medical School, Hannover, Germany

5 Institute for General Medicine, Hannover Medical School, Hannover, Germany and doxylamine for sleep disturbances, also constitute a duplicate prescription.

From a clinical viewpoint, we suggest to differentiate between appropriate and potentially inappropriate duplicate prescriptions (Table 1). In analogy to potentially inappropriate medications (PIMs), i.e. drugs that are considered unsuitable for elderly people [7], we propose the term potentially inappropriate duplicate prescriptions (PIDPs). Deciding whether a duplicate prescription is appropriate or potentially inappropriate represents a challenging task that requires both in-depth clinical and pharmacological knowledge. The evaluation should be performed by a physician or preferably multiple physicians from different specialties for an increased reliability [8,9], and should always consider a patient's individual circumstances such as medication history, comorbidities and patient preferences.

In internal medicine, myriad examples of appropriate duplicate prescriptions (ADPs), i.e. rational and established combination treatments, exist (corresponding indications in parentheses): hydroxymethylglutaryl coenzyme A reductase inhibitor ("statin") + ezetimibe (hypercholesterolemia); opioid analgesic + non-opioid analgesic (postoperative pain); acetylsalicylic acid $+\mathrm{P}_{2} \mathrm{Y}_{12}$ receptor antagonist, e.g. clopidogrel (following coronary stent implantation); loop diuretic + thiazide diuretic (forced diuresis); combination of two antidiabetics of different pharmacological classes, e.g. metformin + sodium-glucose cotransporter type 2 inhibitor. This list is, of course, not exhaustive, and many more examples of ADPs can be thought of.

With regard to PIDPs, we propose a categorisation into three different grades, with higher grades indicating an increasing degree of inappropriateness (Table 1). We believe that our proposed categorisation allows a more subtle differentiation of PIDPs in comparison to previous publications on this topic.

Of note, our categorisation is a simplified model and therefore has certain limitations. Multiplicate (that 
Table 1 Proposal of a differentiation of duplicate prescriptions in appropriate duplicate prescriptions (ADPs) and potentially inappropriate duplicate prescriptions (PIDPs). PIDPs are further subdivided into three grades, with higher grades indicating an increasing degree of inappropriateness. $A C E$, angiotensin-converting enzyme; $A R B$, angiotensin-receptor blocker; $H M G-C o A$, hydroxymethylglutaryl coenzyme A; PPI, proton pump inhibitor; SGLT2, sodium-glucose cotransporter type 2

Duplicate prescriptions

\begin{tabular}{|c|c|c|c|c|}
\hline \multirow[b]{2}{*}{ Grade } & \multirow{2}{*}{$\begin{array}{l}\text { Appropriate duplicate prescrip- } \\
\text { tions (ADPs) } \\
\text { - }\end{array}$} & \multicolumn{3}{|c|}{ Potentially inappropriate duplicate prescriptions (PIDPs) } \\
\hline & & 1 & 2 & 3 \\
\hline Description & $\begin{array}{l}\text { Two drugs with therapeutically } \\
\text { desired synergistic effects (that } \\
\text { is, established combination } \\
\text { treatments) }\end{array}$ & $\begin{array}{l}\text { Two drugs with overlapping } \\
\text { or comparable pharmaco- } \\
\text { dynamics }\end{array}$ & $\begin{array}{l}\text { Two drugs of the same therapeu- } \\
\text { tic class (that is, targeting the } \\
\text { same molecular structure) }\end{array}$ & $\begin{array}{l}\text { Two times the same drug (exceed- } \\
\text { ing the recommended maximum } \\
\text { daily dose) }\end{array}$ \\
\hline \multirow[t]{6}{*}{ Examples } & $\begin{array}{l}\text { HMG-CoA reductase inhibi- } \\
\text { tor + ezetimibe }\end{array}$ & $\mathrm{ACE}$ inhibitor $+\mathrm{ARB}$ & $\begin{array}{l}\text { Two different opioid analgesics } \\
\text { (e.g. buprenorphine + hydro- } \\
\text { morphone; oxycodone + trama- } \\
\text { dol) }\end{array}$ & $\begin{array}{l}\text { Hydrochlorothiazide both as } \\
\text { single agent and as partner in an } \\
\text { antihypertensive combination } \\
\text { product }\end{array}$ \\
\hline & Metformin + SGLT2 inhibitor & ACE inhibitor + aliskiren & $\begin{array}{l}\text { Hydrochlorothiazide + chlortha- } \\
\text { lidone }\end{array}$ & $\begin{array}{l}\text { Valsartan both as single agent and } \\
\text { in sacubitril-valsartan }\end{array}$ \\
\hline & $\begin{array}{l}\text { Opioid analgesic }+ \text { non-opioid } \\
\text { analgesic }\end{array}$ & $\mathrm{PPI}+\mathrm{H}_{2}$ receptor antagonist & Ibuprofen + diclofenac & $\begin{array}{l}\text { Paracetamol both as single agent } \\
\text { and in an acetylsalicylic acid- } \\
\text { paracetamol-caffeine combina- } \\
\text { tion product }\end{array}$ \\
\hline & ACE inhibitor + thiazide diuretic & Paracetamol + ibuprofen & Lorazepam + diazepam & $\begin{array}{l}\text { Ibuprofen both as single agent } \\
\text { and in an ibuprofen-caffeine } \\
\text { combination product }\end{array}$ \\
\hline & Acetylsalicylic acid + clopidogrel & Ibuprofen + metamizole & Amlodipine + lercanidipine & $\begin{array}{l}\text { Diclofenac both as single agent } \\
\text { and in a diclofenac-misoprostol } \\
\text { combination product }\end{array}$ \\
\hline & Loop diuretic + thiazide diuretic & Doxylamine + zopiclone & Diphenhydramine + doxylamine & $\begin{array}{l}\text { Codeine both as single agent and } \\
\text { in a paracetamol-codeine com- } \\
\text { bination product }\end{array}$ \\
\hline
\end{tabular}

is, $\geq$ triplicate) prescriptions are not part of our scheme. We may, for example, think of an elderly gentleman suffering from arterial hypertension who is being treated with a quadruplicate antihypertensive regimen consisting of amlodipine, bisoprolol, moxonidin and hydrochlorothiazide. Evaluation of such a complex therapy requires further knowledge about the patient's comorbidities, comedication and previous medical history including adverse drug reactions and may be considered appropriate or inappropriate, depending on the clinical context. Such an evaluation is clearly beyond the scope of our categorisation.

In conclusion, we propose a differentiation of duplicate prescriptions into appropriate and potentially inappropriate duplicate prescriptions. Furthermore, we suggest subdividing PIDPs into three grades. We strongly encourage fellow physicians to question the appropriateness of duplicate prescriptions in clinical routine and to terminate PIDPs wherever possible, especially grade 3 PIDPs. As with all models, there may be exceptions from the rule. Specialist medications, such as antineoplastic or immunomodulatory agents, should not be discontinued without prior consultation of the prescribing physician.
We hope that the readership may find our proposal convincing and that the term PIDP and its subdivision into three grades will be adopted in future research projects about the clinically relevant topic of duplicate prescriptions.

Author contribution The first draft of the manuscript was written by Johannes Heck, Benjamin Krichevsky, Christoph Höner zu Siederdissen and Olaf Krause. Dirk O. Stichtenoth commented on previous versions of the manuscript. All authors read and approved the final manuscript. This work was supervised by Dirk O. Stichtenoth.

Funding Open Access funding enabled and organised by Projekt DEAL.

\section{Declarations}

Conflict of interest The authors declare no competing interests.

Open Access This article is licensed under a Creative Commons Attribution 4.0 International License, which permits use, sharing, adaptation, distribution and reproduction in any medium or format, as long as you give appropriate credit to the original author(s) and the source, 
provide a link to the Creative Commons licence, and indicate if changes were made. The images or other third party material in this article are included in the article's Creative Commons licence, unless indicated otherwise in a credit line to the material. If material is not included in the article's Creative Commons licence and your intended use is not permitted by statutory regulation or exceeds the permitted use, you will need to obtain permission directly from the copyright holder. To view a copy of this licence, visit http://creativecommons.org/licenses/by/4.0/.

\section{References}

1. Riechelmann RP, Tannock IF, Wang L et al (2007) Potential drug interactions and duplicate prescriptions among cancer patients. J Natl Cancer Inst 99:592-600

2. van Leeuwen RW, Swart EL, Boom FA et al (2010) Potential drug interactions and duplicate prescriptions among ambulatory cancer patients: a prevalence study using an advanced screening method. BMC Cancer 10:679

3. Wetterneck TB, Walker JM, Blosky MA et al (2011) Factors contributing to an increase in duplicate medication order errors after CPOE implementation. J Am Med Inform Assoc 18:774-782
4. Heringa M, Floor A, Meijer WM et al (2015) Nature and management of duplicate medication alerts. J Am Med Inform Assoc 22:831-837

5. Heinze G, Jandeck LM, Hronsky M et al (2016) Prevalence and determinants of unintended double medication of antihypertensive, lipid-lowering, and hypoglycemic drugs in Austria: a nationwide cohort study. Pharmacoepidemiol Drug Saf 25:90-99

6. Kardos P, Geiss F, Simon J et al (2020) Duplicate prescriptions of inhaled medications for obstructive lung diseases. Pneumologie $74: 149-158$

7. Holt S, Schmiedl S, Thuermann PA (2010) Potentially inappropriate medications in the elderly: the PRISCUS list. Dtsch Arztebl Int 107:543-551

8. Lavan AH, Gallagher P, O'Mahony D (2018) Inter-rater reliability of STOPPFrail [Screening Tool of Older Persons Prescriptions in Frail adults with limited life expectancy] criteria amongst 12 physicians. Eur J Clin Pharmacol 74:331-338

9. Lönnbro J, Holmqvist L, Persson E et al (2021) Inter-rater reliability of assessments regarding the quality of drug treatment, and drug-related hospital admissions. Br J Clin Pharmacol. https://doi. org/10.1111/bcp.14790. Epub ahead of print. 